\title{
Diagnosis, presence of endoparasites, and local knowledge on the infestation of the exotic giant African snail (gastropoda: pulmonata: achatinidae), in the urban zone of Rio Branco, Acre, Brazil
}

\author{
Marcos Silva de Lima ${ }^{1 *}$ ib $\&$ Edson Guilherme ${ }^{2}$ \\ ${ }^{1}$ Universidade Federal do Acre, Centro de Ciências Biológicas e da Natureza, Curso de Licenciatura em \\ Ciências Biológicas, BR 364, Km 04, Distrito industrial, CEP: 69.920-900, Rio Branco, AC, Brasil \\ ${ }^{2}$ Universidade Federal do Acre, Laboratório de Ornitologia, BR 364, Km 04, Distrito industrial, \\ CEP: 69.920-900, Rio Branco, AC, Brasil \\ *Corresponding author: Marcos Silva de Lima,e-mail: lima.marcos.ac@gmail.com
}

LIMA, M.S., GUILHERME, E. Diagnosis, presence of endoparasites, and local knowledge on the infestation of the exotic giant African snail (gastropoda: pulmonata: achatinidae), in the urban zone of Rio Branco, Acre, Brazil. Biota Neotropica. 18(3): e20170503. http://dx.doi.org/10.1590/1676-0611-BN-2017-0503

\begin{abstract}
The giant African land snail, Lissachatina fulica is considered to be one of the world's worst invader species. This snail can provoke major economic and public health problems in urban areas, in particular as a potential vector of nematodes that infect both humans and animals. In this context, the present study investigated the extent of the infestation of this exotic snail in the urban neighborhoods of the city of Rio Branco, verified the presence of endoparasites in these snails, and evaluated the knowledge of local residents with regard to the presence of this invader species. For this, daytime surveys were conducted between August 2015 and June 2016. For the analysis of endoparasites, 44 live specimens were sent to the National Reference Laboratory for Schistosomiasis-Malacology (LRNEM) of the Oswaldo Cruz Institute (FIOCRUZ). The knowledge of local residents in the infested neighborhoods was investigated using questionnaires with direct, closed questions. The exotic invader species (L. fulica) was detected in 24 of the 36 neighborhoods visited. A total of 858 L. fulica specimens were collected, of which, 329 were alive and 527 were dead. The total length of the shell ranged from 0.7 to $14.2 \mathrm{~cm}$, with a mean \pm standard deviation of $4.8 \pm 2.21 \mathrm{~cm}$. The density of snails in the areas surveyed varied from 0.34 individuals $/ \mathrm{m}^{2}$ to 3.54 individuals $/ \mathrm{m}^{2}$, while the mean density within the whole study area was estimated to be 0.54 individuals $/ \mathrm{m}^{2}$. Mature eggs were found in only $9(2.7 \%)$ of the 329 specimens dissected. The endoparasitological analysis revealed the presence of rhabditiform larvae in $84 \%$ of the specimens examined, as well as the nematodes Aelurostrongylus abstrusus (22.7\% of the specimens) and Strongyluris sp. (2.2\%). A total of 39 local residents were interviewed, and while all were conscious of the presence of the mollusk, none knew its origin or the most adequate way of dealing with it. The results of the study indicate an ample infestation of the city of Rio Branco by L. fulica, and confirmed a complete lack of intervention on the part of the local authorities for the implementation of measures foe the control and management of this pest within the urban zone of Rio Branco. Keywords: Aelurostrongylus abstrusus; Lissachatina fulica; Strongyluris sp.; Southwest Amazon.
\end{abstract}

\section{Diagnóstico, presença de endoparasitas e conhecimento local sobre a infestação do caracol gigante exótico africano (gastropoda: pulmonata: achatinidae), na zona urbana de Rio Branco, Acre, Brasil}

\footnotetext{
Resumo: Conhecido como caracol gigante africano a espécie Lissachatina fulica é considerada uma das piores espécies invasoras do mundo. Em áreas urbanas pode causar grandes problemas econômicos e para a saúde pública por ser um potencial vetor de nematódeos de interesse médico e veterinário. Desta forma, o presente trabalho teve como objetivos averiguar a extensão da infestação do caracol exótico nos bairros da zona urbana da cidade de Rio Branco; verificar a presença de endoparasitos, bem como avaliar o conhecimento da população local em relação a presença desta espécie invasora. Para isso, foram realizadas coletas diurnas no período de agosto de 2015 a junho de 2016. Para verificar a presença de endoparasitos foram enviados 44 indivíduos vivos ao Laboratório de
} 
Lima, M.S. \& Guilherme, E.

Referência Nacional para Esquistossomose-Malacologia (LRNEM) da Fundação Oswaldo Cruz (FIOCRUZ). A avaliação do grau de conhecimento dos moradores dos bairros infestados deu-se pela utilização de questionários com perguntas fechadas e diretas. A espécie exótica e invasora (L. fulica) foi detectada em 24 dos 36 bairros visitados. Dos 858 indivíduos coletados, 329 estavam vivos e 527 mortos. O comprimento total das conchas variou de 0,7 a 14,2 cm com uma média \pm desvio padrão de 4,8 $\pm 2,21 \mathrm{~cm}$. A densidade de indivíduos nas áreas amostradas variou do mínimo de 0,34 ao máximo de 3,54 indivíduos $/ \mathrm{m}^{2}$ enquanto que a densidade média de espécimes tendo como base a área total amostrada foi de 0,54 indivíduos $/ \mathrm{m}^{2}$. Somente em 2,7\% (9) dos 329 espécimes dissecados foram encontrados ovos maduros. A busca por endoparasitos revelou a presença larvas rabditiformes em $84 \%$ dos espécimes investigados além dos nematódeos Aelurostrongylus abstrusus (22,7\%) e Strongyluris sp. (2,2\%). Ao todo foram entrevistados 39 moradores, onde verificou-se que eles têm consciência da presença do molusco mas desconhecem sua origem e a forma de manejá-lo adequadamente. Nossos resultados apontam para uma ampla infestação da espécie L. fulica na cidade de Rio Branco e constata a total ausência do poder público no que diz respeito a implementação de medidas de controle e manejo desta praga nos limites da cidade.

Palavras-chave: Aelurostrongylus abstrusus; Lissachatina fulica; Strongyluris sp.; Sudoeste da Amazônia.

\section{Introduction}

The giant African land snail, Lissachatina fulica (Bowdich 1822), is considered to be one of the world's 100 most important invader species (Sridhar et al. 2014, Gisd 2018). Native to eastern Africa, this snail was introduced to Mauritius in the 1800 s, from where it spread rapidly throughout the islands of the Indian and Pacific oceans (Sankaran 2004, Tatayah et al. 2007). The species is now found in many countries throughout the world, including India, Sri Lanka, Malaysia, Australia, Japan, the United States, and almost all of South America, including Brazil (Fontanilla et al. 2014, Sridhar et al. 2014). In Brazil, L. fulica was introduced into the southern state of Paraná in the mid-1980s (Thiengo et al. 2007), with the aim of producing a commercially viable alternative to the smaller, edible European garden snail (Helix aspersa Müller, 1774), known as the "escargot", which is reared on a large scale for human consumption in many countries (Murphy 2001). Producers initially aimed to export the snail to Europe and, eventually, supply the Brazilian market, but while this operation was successful for a while, exportation eventually became unprofitable, and the producers were unable to establish a viable domestic market, given the lack of a culinary tradition in Brazil (Colley \& Fischer 2009). The producers then released the remaining snails into the wild.

The capacity of the giant african land snail to adapt to a diversity of habitats, the absence of natural predators, and its generalist habits and high reproductive rates, have all contributed to its dispersal throughout the warm and humid regions of the globe, including the whole of Brazil (Fischer \& Colley 2004, Coelho 2005, Fischer \& Colley 2005, Thiengo et al. 2007, Fontanilla et al. 2014, Sridhar et al. 2014). As an invader species, L. fulica is a potential competitor of native mollusk species (Sankaran 2004). The giant african land snail is basically herbivorous, with no particular preference for any given plant species, which makes it a potentially important agricultural pest (Sankaran 2004). The species is a vector of nematode parasites to other animals, and also transmits parasites that threaten human health, such as nematodes of the genus Angiostrongylus Kamensky 1905 (Jarvi et al. 2012, Caldeira et al. 2007, Gisd 2018).

In the Americas, the first recorded case of eosinophilic meningitis in humans was registered in Cuba, in 1981 (Aguiar et al. 1981) and the disease spread rapidly to neighboring countries, such as the Dominican
Republic, Haiti, Puerto Rico, and the United States (Lai et al. 1982, Andersen et al. 1986, Raccurt et al. 2003, Hochberg et al. 2007). In Brazil, eosinophilic meningitis spread by the nematode Angiostrongylus cantonensis (Chen 1935) was first reported in the state of Espírito Santo, in 2007 (Caldeira et al. 2007), and more recently in Pernambuco (Lima et al. 2009) and São Paulo (Espírito-Santo et al. 2013). In all three cases, the presence of L. fulica was confirmed in the areas adjacent to the residences of the individuals diagnosed with the parasite. Given its ample spectrum of neurological symptoms, eosinophilic meningitis has been commonly referred to as neural Angiostrongyliasis (Hung \& Chen 1988). The incidental presence of the nematode Angiostrongylus costaricensis Morera and Céspedes 1971 has also been confirmed in a child in Espirito Santo, Brazil (Pena et al. 1995). It is important to note that a number of rat species are the definitive vectors of the nematodes $A$. costaricensis and A. costaricensis, which cause eosinophilic meningitis and abdominal angiostrongyliasis, respectively, in humans (Morera \& Céspedes 1971, Morassutti et al. 2014). However, these nematodes are much less specific in relation to their intermediate hosts, and may parasitize a diversity of mollusks, including both terrestrial and freshwater species (Wallace \& Rosen 1969 (b), Mota \& Lenzi 1995, Thiengo et al. 2013 (b)). In humans, infection may occur through the ingestion of fruit, leaves or other foods which have come into contact with the mucous of the intermediate host, typically a terrestrial gastropod, and have been washed inadequately (Moreira et al. 2013).

In many studies of the exotic giant African land snail in the Americas, the species has been classified as Achatina (Lissachatina) fulica (e.g., Thiengo et al. 2007). However, in a molecular study, Fontanilla (2010) found significant differences between the populations of East Africa, assigned to the subgenus Lissachatina, and those from Central and West Africa, classified as Achatina. Based on these findings, we consider Lissachatina to be a full genus, a recommendation adopted in many recent studies (e.g., Smith et al. 2013, Fontanilla et al. 2014, Iwanowicz 2015).

The giant African land snail is currently found in 25 of the 26 Brazilian states, as well as the Federal District (Thiengo \& Fernandez 2013 (a)). Few data are available on the occurrence of this species in Brazilian Amazonia. Thiengo et al. (2007) recorded the occurrence of L. fulica in the northern Brazilian states of Amazonas, Rondônia, 
Pará, and Mato Grosso. Oliveira et al. (2013) confirmed the presence of this species in the state of Amapá while newspaper reports from 2014, available on the internet, refer to its presence in Boa Vista, capital of Roraima. This meant that Acre was the only state in which the presence of $L$. fulica had not been recorded, although the presence of $L$. fulica in Rio Branco had been confirmed through the collection of a shell by EG in the Zoobotanical Park of the Federal University of Acre (UFAC). This shell was sent to the Malacology collection of the Zoology Museum of São Paulo University (USP), where it was deposited under catalog number MZSP-98749. In addition to Rio Branco, L. fulica is known to occur in other towns in Acre, including Acrelândia, Xapuri and Brasiléia (E.G. pers. obs.). While this invader species appears to be relatively widespread in the state, there have been no previous studies in Acre.

Given this, the present study aimed to (a) verify the occurrence of L. fulica in the urban neighborhoods of the city of Rio Branco, capital of Acre, (b) determine whether this population includes individuals infected with the larvae of parasites of medical importance to humans or animals, and (c) verify whether the residents of the affected neighborhoods recognize L. fulica as an invader species that poses a public health risk, and the appropriate management measures.

\section{Materials and Methods}

\section{Sampling area}

The present study focused on the urban zone of the municipality of Rio Branco, in the Brazilian state of Acre (Figure 1), which borders Peru and Bolivia, and the Brazilian states of Amazonas and Rondônia. The city is located on the Acre River, and the municipality has a total area of $8.835,541 \mathrm{~km}^{2}$.
We visited 36 neighborhoods within the urban zone of Rio Branco to confirm the presence/absence of L. fulica. We searched vacant lots, household gardens and backyards, and public parks (Figure 1). Data were collected over an 11-month period, from August 2015 to June 2016, between 14h:00 and 18h:00, by a single collector. Each neighborhood was surveyed visually for signs of the presence of the animal, such as shells, shell fragments, feces, eggs or live animals. Local residents were also consulted for information on the presence of the mollusk within the area of each neighborhood. During each visit, the area was surveyed for mollusks during three hours, and local residents were interviewed during one hour. Each site was visited only once during the study period.

\section{Data collection}

When the presence of $L$. fulica was detected, all the specimens were collected, irrespective of their size or condition (dead or alive), using disposable gloves. During the collection, the biological data (body size, and the number of dead and living individuals) were noted on a standard form, together with information on the site (area of the site, and whether it was a residential property or a vacant lot) (Table 1). In the laboratory, all the specimens were washed, measured with a calliper and then deposited in the UFAC malacology collection. Population density was calculated by dividing the area of each site $\left(\mathrm{m}^{2}\right)$ by the number of specimens (dead and alive) encountered.

\section{Presence of mature eggs}

All the live specimens with a shell longer than 5.5 centimeters were housed in terrariums until dissection. The specimens were dissected to confirm the presence of mature (encased) eggs. Reproductive activity was confirmed when mature eggs were found in the reproductive organs of the specimens (Teixeira et al. 2008). All the eggs found in each specimen were counted and measured using a ruler.

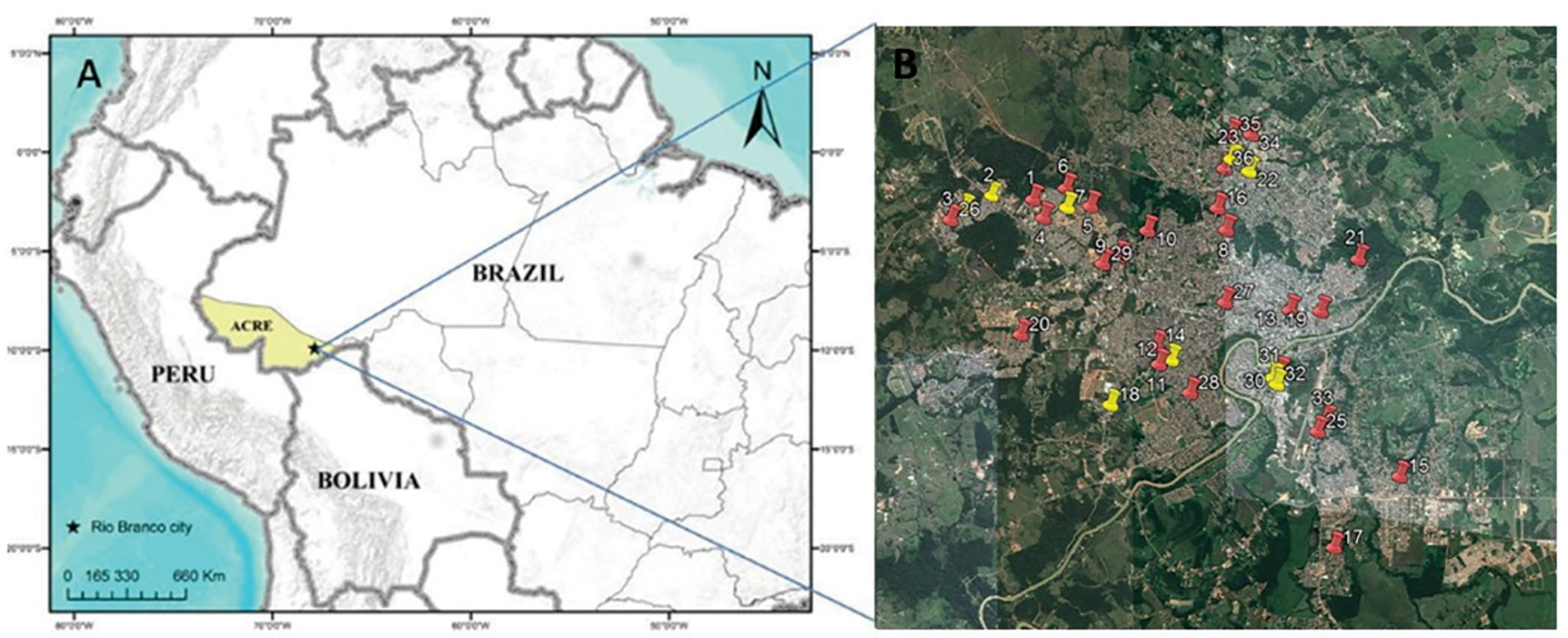

Figure 1. A - Location of Acre in Brazil. B - Satellite image of the city of Rio Branco. The numbered points indicate the neighborhoods visited during the present study, in chronological order. The red points indicate the neighborhoods infested with L. fulica and the yellow points, the neighborhoods in which the mollusk was not found during the survey: 1-Distrito Industrial; 2- Universitário II; 3- Universitário I; 4- Tucumã; 5-Bairro Rui Lino; 6- Mocinha Magalhães; 7-Conjunto Rui Lino; 8-Bairro da Paz; 9- Esperança; 10- Geraldo Fleminger; 11- João Eduardo II; 12- Betel I; 13- Capoeira; 14-Betel II; 15-Belo Jardim; 16-Vila Ivonete; 17- Santa Helena; 18- Floresta; 19- Habitasa; 20-Calafate; 21-Morada do Sol; 22-Vitória; 23-Chico Mendes; 24- Eldorado; 25-Recanto dos Buritis; 26-Universitário III; 27-Abrahão Alab; 28-Bahia Nova; 29- Conjunto Mariana; 30-Triângulo; 31-Triângulo Velho; 32- Triângulo Novo; 33-Jacarandá; 34-Parque dos Sábias; 35-Adalberto Sena; 36-Placas. Source: GoogleEarth ${ }^{\circledR}$. 
Lima, M.S. \& Guilherme, E.

Table 1. Neighborhoods of the city of Rio Branco surveyed for the presence of the invader mollusk L. fulica.

\begin{tabular}{|c|c|c|c|c|c|}
\hline Neighborhood & Street & Date & $\begin{array}{c}\text { Number of } \\
\text { specimens found* }\end{array}$ & Geographic coordinates & $\begin{array}{c}\text { Area in which the specimens } \\
\text { were collected }\left(\mathrm{m}^{2}\right)\end{array}$ \\
\hline Distrito Industrial & Rua das Acácias & $08 / 20 / 2015$ & 24 & $\begin{array}{c}09^{\circ} 56^{\prime} 41.0 ” \mathrm{~S} \\
067^{\circ} 51^{\prime} 59.3 ” \mathrm{~W}\end{array}$ & 168,85 \\
\hline Universitário II & Not found & $09 / 01 / 2015$ & 0 & $\begin{array}{l}09^{\circ} 56^{\prime} 39.12^{\prime \prime} \mathrm{S} \\
067^{\circ} 52^{\prime} 34.2^{\prime \prime} \mathrm{W}\end{array}$ & 0 \\
\hline Universitário I & Not found & $09 / 02 / 2015$ & 0 & $\begin{array}{c}09^{\circ} 56^{\prime} 49.04^{\prime \prime S} \\
067^{\circ} 52^{\prime} 56.66^{\prime \prime} \mathrm{W}\end{array}$ & 0 \\
\hline Distrito Industrial & Setor C & $09 / 23 / 2015$ & 0 & $\begin{array}{l}09^{\circ} 56^{\prime} 38.4^{\prime \prime} \mathrm{S} \\
067^{\circ} 53^{\prime} 9.0^{\prime \prime} \mathrm{W}\end{array}$ & 0 \\
\hline Tucumã & $\mathrm{N}-1$ & $09 / 25 / 2015$ & 6 & $\begin{array}{l}09^{\circ} 56^{\prime} 58.18^{\prime \prime S} \\
067^{\circ} 51^{\prime} 50.1^{\prime \prime} \mathrm{W}\end{array}$ & 14,64 \\
\hline Conjunto Rio Lino & Not found & $09 / 28 / 2015$ & 0 & $\begin{array}{c}09^{\circ} 56^{\prime} 49.13 " \mathrm{~S} \\
067^{\circ} 51^{\prime} 29.66^{\prime \prime} \mathrm{W}\end{array}$ & 0 \\
\hline Tucumã & $\mathrm{N}-3$ & $09 / 30 / 2015$ & 13 & $\begin{array}{l}09^{\circ} 56^{\prime} 54.44^{\prime \prime} \mathrm{S} \\
067^{\circ} 51^{\prime} 45.8^{\prime \prime} \mathrm{W}\end{array}$ & 68,0 \\
\hline Tucumã & RW-1 & $10 / 01 / 2015$ & 8 & $\begin{array}{c}09^{\circ} 57^{\prime} 12.4^{\prime \prime} \mathrm{S} \\
067^{\circ} 51^{\prime} 37.5^{\prime \prime} \mathrm{W}\end{array}$ & 107,0 \\
\hline Tucumã & $\mathrm{W}-5$ & $10 / 01 / 2015$ & 8 & $\begin{array}{c}09^{\circ} 57^{\prime} 6.4^{\prime \prime S} \\
067^{\circ} 51^{\prime} 37.2^{\prime \prime} \mathrm{W}\end{array}$ & 20 \\
\hline Bairro da Paz & Travessa Natal & $10 / 14 / 2015$ & 31 & $\begin{array}{c}09^{\circ} 57^{\prime} 09.7^{\prime \prime S} \\
067^{\circ} 49^{\prime} 14.7^{\prime \prime} \mathrm{W}\end{array}$ & 74,21 \\
\hline Betel I & Not found & $10 / 28 / 2015$ & 0 & $\begin{array}{c}09^{\circ} 58^{\prime} 56.23 " \mathrm{~S} \\
067^{\circ} 50^{\prime} 07.19^{\prime \prime} \mathrm{W}\end{array}$ & 0 \\
\hline Capoeira & Maria Amélia & $11 / 05 / 2015$ & 15 & $\begin{array}{c}09^{\circ} 58^{\prime} 16.2^{\prime \prime S} \\
067^{\circ} 48^{\prime} 22.5^{\prime \prime} \mathrm{W}\end{array}$ & 35,90 \\
\hline Betel II & 25 de dezembro & $11 / 10 / 2015$ & 15 & $\begin{array}{c}09^{\circ} 58^{\prime} 55.7^{\prime \prime S} \\
067^{\circ} 50^{\prime} 35.6^{\prime \prime} \mathrm{W}\end{array}$ & 43,05 \\
\hline Belo Jardim & Das Flores & $11 / 14 / 2015$ & 11 & $\begin{array}{c}10^{\circ} 00^{\prime} 33.98^{\prime \prime S} \\
067^{\circ} 46^{\prime} 51.30^{\prime \prime} \mathrm{W}\end{array}$ & 32 \\
\hline Vila Ivonete & Serena nogueira & $11 / 16 / 2015$ & 33 & $\begin{array}{l}09^{\circ} 56^{\prime} 52.26^{\prime \prime} \mathrm{S} \\
67^{\circ} 49^{\prime} 22.67^{\prime \prime} \mathrm{W}\end{array}$ & 33 \\
\hline L. Santa Helena & Not found & $11 / 18 / 2015$ & 7 & $\begin{array}{l}10^{\circ} 1 ' 35.52^{\prime \prime S} \\
67^{\circ} 47^{\prime} 46.42^{\prime \prime O}\end{array}$ & 85,59 \\
\hline Floresta & Not found & $12 / 09 / 2015$ & 0 & $\begin{array}{c}10^{\circ} 1^{\prime} 30.29 " \mathrm{~S} \\
067^{\circ} 47^{\prime} 41.81^{\prime \prime} \mathrm{W}\end{array}$ & 0 \\
\hline Habitasa & Venezuela & $12 / 29 / 2015$ & 12 & $\begin{array}{l}9^{\circ} 58^{\prime} 18.75^{\prime \prime} \mathrm{S} \\
67^{\circ} 47^{\prime} 56.19 " \mathrm{~W}\end{array}$ & 20 \\
\hline
\end{tabular}


Continued Table 1.

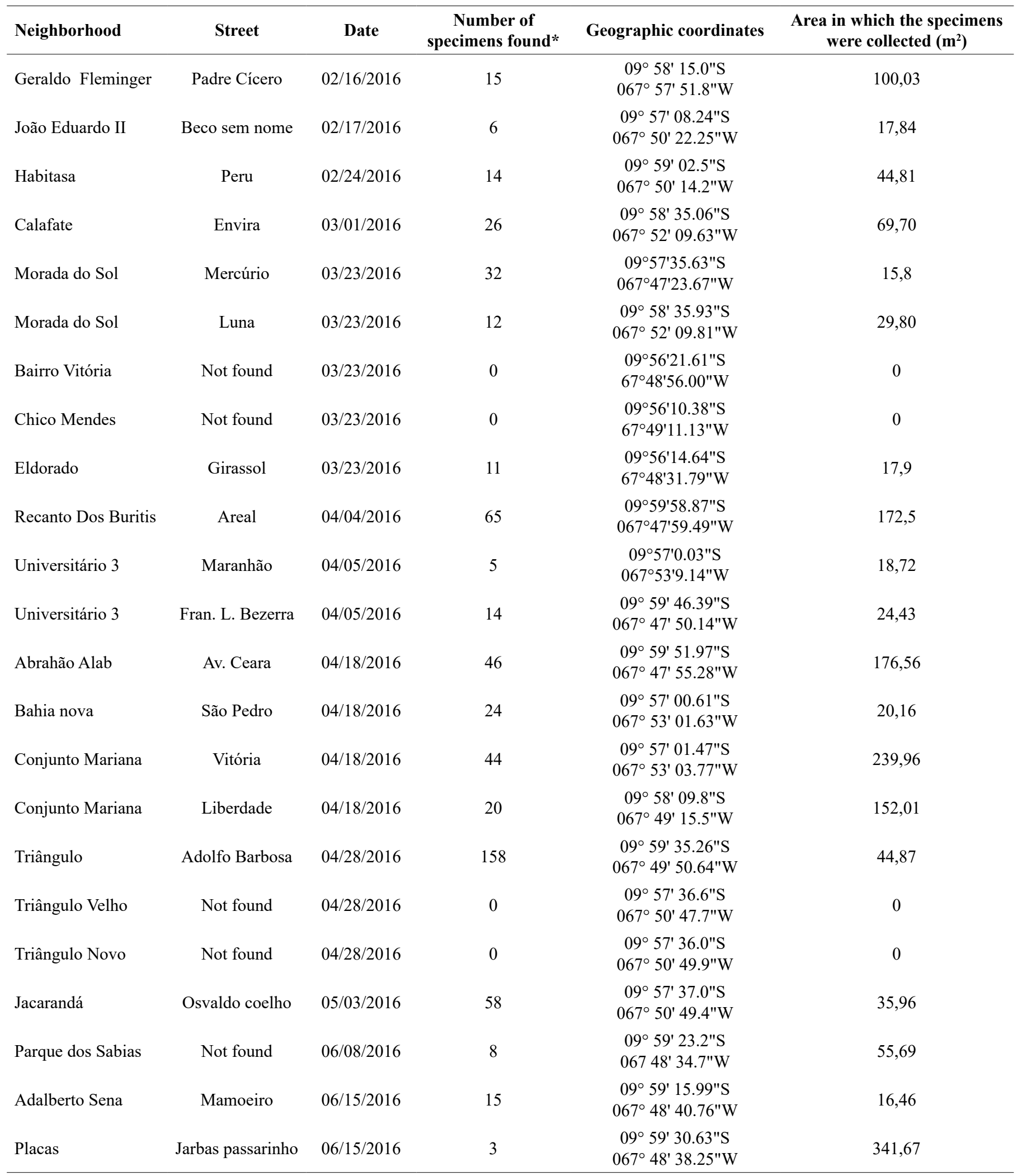

This column shows only the specimens collected for the morphometric measurements and dissection. The specimens obtained for parasitological analysis were collected specifically for this purpose on other days (Table 2). 


\section{Presence of endoparasites}

To determine the possible infection of snails by nematodes of medical-veterinary relevance, 44 live specimens were collected in 11 different neighborhoods (four specimens per neighborhood) in the urban zone of Rio Branco. The neighborhoods were selected randomly by lottery for the survey. A subsample of 44 specimens was collected specifically for the analysis of the presence of endoparasites, and for this reason, they are not included in the total number of individuals measured and dissected (Table 1). The specimens collected were sent to the National Reference Laboratory for Schistosomiasis-Malacology (LRNEM) of the Oswaldo Cruz Institute (FIOCRUZ) in Rio de Janeiro, where they were digested artificially using the technique proposed by Wallace \& Rosen (a) (1969).

\section{Interviews with residents}

During the collection of samples, residents of the neighborhoods in which the snail was found were interviewed using a questionnaire that investigated the knowledge of the residents on the giant African land snail, L. fulica. The name, age, and sex of each interviewee were recorded, as well as the length of time they had lived in the neighborhood. The questions referred to (i) the knowledge of the resident with regard to the animal, (ii) the name used to refer to the species, (iii) its origin, (iv) where and when the snail was observed most frequently, (v) what measures are taken, if any, when the animal is encountered in the proximity of the household, (vi) if the mollusk is known to transmit any diseases, (vii) whether the local public health authorities have alerted the resident to any risk associated with the species, (viii) if the interviewee knows how the species arrived in the state, and in particular, Rio Branco, and (ix) whether it is known to cause any problems for the environment or the local population. The knowledge of the infested neighborhoods was investigated using questionnaires with direct, closed questions. The responses to the questions were tabulated and organised in classes of answers. Following the interviews, the participants were alerted to the potential dangers associated with L. fulica, and the measures that can be taken to eliminate the species.

This study was conducted according to the current institutional norms governing animal research in Brazil. The project on which the study was based was approved by the UFAC ethics committee for the use of animals in research, under protocol number 59/2015. The collection of specimens of the exotic snail, L. fulica, is permitted by normative instruction 18/2005 of the Brazilian Federal Environment Institute (IBAMA), which authorizes the control and elimination of the species.

\section{Results}

The L. fulica was detected in $24(66.6 \%)$ of the neighborhoods visited during the present study, with no individuals being detected in only twelve (33.4\%) neighborhoods (Table 1). A total of 858 specimens $(=34.32 \pm 31.98$ SD individuals per site; median $=26)$, were collected, including 329 live individuals (=13.16 $\pm 18.31 \mathrm{SD}$; median = 8), and 529 shells $(=21.08 \pm 20.07 \mathrm{SD}$; median $=12)$ per site. The largest number of individuals was recorded in the Triângulo neighborhood, where 158 specimens ( 90 alive), representing $18.41 \%$ of the total number of specimens, were collected, whereas only three dead shells, $0.34 \%$ of the sample, were collected in the Placas neighborhood (Table 1). No snails were detected during the survey in a number of neighborhoods, including Mocinha Magalhães, Conjunto Rui Lino, Floresta, Vitória, and Chico Mendes (Table 1). Density varied from a minimum of 0.34 to a maximum of 3.54 individuals $/ \mathrm{m}^{2}$, with a mean of $1.89 \pm 2.76 \mathrm{SD}$ individuals $/ \mathrm{m}^{2}$. The mean density of snails over the whole study area was 0.54 individuals $/ \mathrm{m}^{2}$.

\section{Presence of mature eggs}

Only nine of the 329 live specimens presented mature eggs in the oviduct. A total of 526 eggs were found, which measured $4.3 \pm 0.57 \mathrm{~mm}$, on average. The number of reproductive specimens represented only $2.7 \%$ of the live individuals encountered during the surveys.

\section{Morphometry (total length)}

In all, 760 of the 858 specimens collected had an intact (unbroken) shell, which was measured. Total length ranged from 0.7 to $14.2 \mathrm{~cm}$, with a mean \pm standard deviation of $4.8 \pm 2.21 \mathrm{~cm}$ (Figure 2). Most (570 specimens; $75 \%$ ) of the individuals measured between 2.1 to $7 \mathrm{~cm}$ in length (Figure 2). Smaller (shells smaller than $3 \mathrm{~cm}$ ) individuals were found more frequently between August 2015 and March 2016 (Figure 2 ), and most of the individuals in all size classes were collected during this period.

\section{Presence of endoparasites}

None of the 43 L. fulica specimens analyzed (one specimen was dead on arrival at the LRNEM, which impeded analysis) from 11 different neighborhoods of Rio Branco were infected by larvae of the nematodes A. cantonensis or A. costaricensis. However, rhabditiform larvae were identified in almost all the specimens ( $\mathrm{n}=37$ or $84 \%$ ), in addition to two nematodes, Aelurostrongylus abstrusus (Railliet, 1898) (Nematoda:

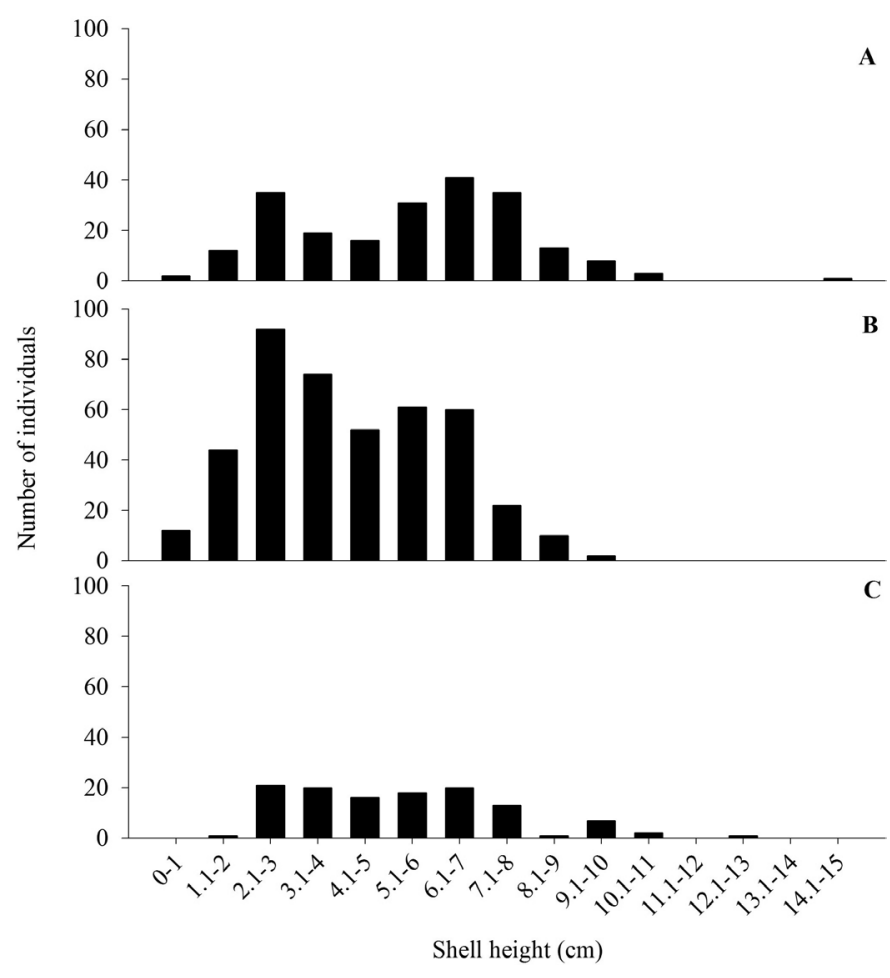

Figure 2. Size classes of total shell length $(\mathrm{cm})$ of the L. fulica specimens collected in the city of Rio Branco between August 2015 and June 2016. A: August to November; B: December to March, and C: April to June. 
Diag. Pres. Endo, loc know. Exotic. Afri. Snail.

Table 2. Results of the analyses of the L. fulica specimens collected in the different neighborhoods of Rio Branco, Acre, Brazil.

\begin{tabular}{lcc}
\hline Neighborhoods & Samples analyzed* & Endoparasites \\
\hline Tucumã & 4 & Rhabditiform larvae (4)** \\
Belo Jardim & 4 & Rhabditiform larvae (3), Aelustrongylus abstrusus (2) \\
Betel I & 4 & Rhabditiform larvae (4), Aelustrongylus abstrusus (3) \\
João Eduardo II & 4 & Rhabditiform larvae (4), Aelustrongylus abstrusus (2) \\
Bairro da Paz & 4 & Rhabditiform larvae (2), Aelustrongylus abstrusus (1) \\
Geraldo Fleminger & 4 & Rhabditiform larvae (2), Aelustrongylus abstrusus (1) \\
Capoeira & 4 & Rhabditiform larvae (3) \\
Distrito industrial & 4 & Rhabditiform larvae (4) \\
Morada do Sol & 4 & Rhabditiform larvae (4), Aelustrongylus abstrusus (1) \\
Vila Ivonete & 4 & Rhabditiform larvae (4), Strongyluris sp. (1) \\
Habitasa & 3 & Rhabditiform larvae (3) \\
\hline
\end{tabular}

* Only 43 of the 44 specimens sent for analysis were alive when they arrived at the laboratory and could be analyzed. ** The values in parentheses are the number of the L. fulica specimens analyzed that were infected by the respective nematode species.

Metastrongylidae) $(\mathrm{n}=10$ or $22.7 \%)$ and Strongyluris sp. Mueller, 1894 (Nematoda: Heterakidae) ( $\mathrm{n}=1$ or $2.2 \%$ ) (Table 2$)$.

\section{Knowledge of the local population on the exotic snail}

Thirty-nine residents were interviewed in the different neighborhoods of Rio Branco, of which, 29 (74.3\%) were female. The mean age of the 39 interviewees was $47.4 \pm 16.0$ years (range: $17-79$ years old). Just under half $(\mathrm{n}=18$ or $46.1 \%)$ of the interviewees had lived in their current neighborhood for 11-20 years, nine (23.0\%) for 1-9 years, five (12.8\%) for $21-30$ years, five (12.8\%) for more than 30 years, and two $(5.1 \%)$ for less than one years. The oldest memories of the presence of the African land snail in Rio Branco data back to 2005, that is, 11 years prior to the present study, while the largest proportion $(30.7 \%)$ of the interviewees only perceived the presence of the species in the neighborhood from 2014 onward.

None of the interviewees were familiar with the vernacular name by which L. fulica is known in Brazil ("caramujo gigante africano" = giant African land snail) or its scientific name. Most ( $\mathrm{n}=26$ or $66.6 \%)$ of the interviewees referred to the animal as a caracol (snail), seven (17.9\%) named it "buzu", five (12.8\%) as a caramujo (conch or water snail), and one (2.1\%) as a lesma (slug).

The vast majority of the interviewees ( $n=31$ or $79 \%$ ) were unaware of the origin of the species, while the other $21 \%(n=8)$ believed that it is native to the Amazon region. The vast majority (33 or $84.6 \%$ ) of the interviewees confirmed that the species is observed more often during the rainy season months. Around a third $(n=10$ or $25.6 \%)$ of the interviewees confirmed that the animal was typically found after rainfall, $11(28.2 \%)$ in the morning, $10(25.6 \%)$ at night, and eight $(20.5 \%)$ at any time of day.

Most interviewees $(n=14)$ referred to the walls of houses as the location where the greatest concentrations of $L$. fulica could be found. Others indicated the most humid areas of the garden ( $\mathrm{n}=6$ interviewees), vegetable gardens $(n=5)$, on waste ground $(n=4)$, vacant lots $(n=3)$, near water tanks $(n=3)$, and in piles of rubble $(n=2)$ or streams $(n=2)$.

When asked where the animal seeks refuge from the sun and high temperatures, most of the interviewees (74\%) confirmed that they were unfamiliar with the ecological strategies of the species.
More than half of the interviewees admitted not knowing how the animal arrived in the state or the city of Rio Branco. The others confirmed that the species came "crawling", by plane or truck, and so on.

When asked whether the animal was a vector of diseases, most (58.9\%) of the interviewees believed that L. fulica does contribute to the transmission of diseases, but were unable to identify these diseases. A considerable percentage of the interviewees confirmed that the snail does not transmit disease. The residents who referred to specific diseases mentioned Ascites ( $\mathrm{n}=2$ interviewees), schistosomiasis $(\mathrm{n}=$ $1)$, "worms" $(\mathrm{n}=1)$, and skin infections $(\mathrm{n}=1)$.

The interviewees were clearly inconvenienced by the presence of the mollusks in their residences and adjacent areas, and a majority (71\%) dealt with these animals by killing them. Other individuals reported dealing with the mollusks in a number of other ways. All of the interviewees confirmed that they had never been visited by a public health agent or other government official with information on the snail or the risks of contact with this animal.

\section{Discussion}

The exotic giant African land snail, L. fulica, is found throughout the urban area of the Brazilian city of Rio Branco, capital of the Brazilian state of Acre. The presence of a large number of individuals of all sizes, including juveniles and (sexually active) adults in the neighborhoods visited indicates that the L. fulica populations are fully established in the metropolitan region of this city.

In the present study, L. fulica was found to be abundant in some areas of certain neighbourhoods, whereas in others, it was quite rare. A similar pattern of variation in the distribution of the mollusk was observed by Fischer \& Colley (2004) in Guaraqueçaba, on the northern coast of the Brazilian state of Paraná. The mean density of L. fulica recorded in the areas surveyed in Rio Branco was lower than that registered in Puyo, Ecuador (3.7 ind $/ \mathrm{m}^{2}$; Gołdyn et al. 2016), but higher than that recorded in some Brazilian cities (e.g., Miranda et al. 2004). Some authors (e.g., Thiengo et al. 2007, Gołdyn et al. 2017) consider high densities of this species to be a characteristic of the initial stages of infestation. Only a small number of live individuals contained mature eggs. This finding 
was similar to that of Roda et al. (2016), who found eggs in only a small proportion (5\%) of the L. fulica specimens they analyzed. Fisher \& Colley (2005) and Roda et al. (2016) reported finding adults laying eggs throughout the year. In Rio Branco, however, specimens containing eggs were only collected between December and March, the rainiest part of the year in this region (Duarte 2006). This difference may reflect the influence of the climate of the Southwestern Amazon basin on the reproductive patterns of the species, although more detailed, long-term data will be required to confirm any such effect, and its determinants.

The morphometric parameters recorded for the L. fulica populations in Rio Branco were compatible with those registered in other studies (Fisher \& Colley 2005, Albuquerque et al. 2009, Roda et al. 2016, Gołdyn et al. 2017). In Guaraqueçaba, in the Brazilian state of Paraná, Fischer \& Colley (2005) recorded a mean L. fulica shell length of 5.2 $\mathrm{cm}$. In Lauro de Freitas, in the state of Bahia, L. fulica specimens of up to $10.25 \mathrm{~cm}$ in length were collected by Albuquerque et al. (2009), with a mean of $4.2 \mathrm{~cm}$, values very similar to those recorded in the present study, i.e., a mean of $4.82 \mathrm{~cm}$ and a maximum of $14.2 \mathrm{~cm}$. Most of the specimens collected in Rio Branco were between 2.1 to $7.0 \mathrm{~cm}$ in length, indicating a relatively young population, with individuals being yet to reach the maximum size of the species. Older individuals (with shells of more than $10 \mathrm{~cm}$ in length) make up only $0.95 \%$ of the total sample. In a similar study in Puyo, Ecuador, Gołdyn et al. (2017) obtained similar results to those of the present study, i.e., a predominance of subadults, and concluded that the reproductive biology of L. fulica is of the $r$ strategist type. While plausible, this hypothesis requires more conclusive data, given that Roda et al. (2016) recorded gestating specimens with shell lengths of between 4.8 to $12.8 \mathrm{~cm}$, even though individuals of less than $6.5 \mathrm{~cm}$ contributed fewer eggs than those larger than $9.0 \mathrm{~cm}$.

The movements and dispersal of $L$. fulica vary according to the stage of the life cycle and the season (Tomiyama \& Nakane 1993, Raut \& Barker 2002). Young animals are generally more capable of dispersing than adults, although the absolute dispersal capacity is still limited. Tomiyama \& Nakane (1993) found that L. fulica can disperse as much as $500 \mathrm{~m}$ in six months. This indicates that juvenile individuals can reach and colonize adjacent neighborhoods, although the species did not reach Rio Branco through a natural process of dispersal.

It is unclear how the species arrived in Acre. As no evidence was found of a deliberate process of introduction, the most probable source of the infestation was the accidental transportation of the snail in cargos from other regions of Brazil or the neighboring countries of Peru and Bolivia, where L. fulica is also known to occur (Sridhar et al. 2014).

The establishment of the giant African land snail in Rio Branco is a cause for concern, given that this generalist species has an enormous potential for proliferation (Fischer \& Colley 2005). There are few reports of predation by native Brazilian animals (Martins \& Donatelli 2014), which implies that there is little potential for natural control mechanisms of the species populations. This was confirmed in the present study through the detection of the larvae of $A$. abstrusus, which causes pneumonia in cats (Silva et al. 2005) and Strongyluris sp., a parasite of wild lizards (Santos et al. 2013). The larvae of A. abstrusus have also been found infecting L. fulica in a number of Brazilian states (Thiengo et al. 2008, Ohlweiler et al. 2010), although there is no evidence of the transmission of these larvae to domestic cats. A number of the specimens analyzed presented co-infection between
A. abstrusus and rhabditiform larvae of other helminths (possibly Strongyluris sp.). The co-infection of L. fulica by multiple helminth species was reported by Oliveira et al. (2015) in the region of São Gonçalo, in the state of Rio de Janeiro. The co-infection of mollusks by helminths and other parasites may indicate a severe and chronic level of local infestation (Bonfim et al. 2013), which cannot be ruled out in the case of the L. fulica population of Rio Branco. The specimens collected in the present study in Rio Branco did not contain the larvae of nematodes that cause diseases in humans. It is nevertheless possible that snails infected with the larvae of A.cantonensis may still be found in the L. fulica populations of Rio Branco, given that snails infected with the larvae of this nematode have been collected in other region of Brazil (Morassutti et al. 2014).

The ethno-ecological data (interviews) indicate that the local population is aware of the presence of this exotic mollusk in the city. However, few of the residents interviewed were aware of the origin of the animal or the risks it represents for the health of human populations and domestic animals or family agriculture (kitchen gardens). The relatively recent memories of the interviewees with regard to the presence of $L$. fulica in Rio Branco implies that the species arrived in the city very recently. However, $L$. fulica arrived in Acre much earlier, given that one of the authors (E.G. pers. obs.) obtained reports of its presence in the town of Acrelândia, in the eastern extreme of the state, in 2008.

A number of the interviewees referred to L. fulica as the "buzu", which is the vernacular name used by the region's rubber-tappers and other forest dwellers to refer to the mollusk Megalobulimus sp. Miller, 1878 (Megalobulimidae) which is native to Southwestern Amazonia, and is relatively common in the local forests. By confusing the invader mollusk with the native species, the local residents are overlooking the potential risks that the presence of this species represents for the local environment and the health of local human populations. In general, the population is aware of the presence of the animal when it appears in large numbers in houses and on waste ground, which typically occurs after torrential downpours or during major floods. This result is similar to the findings of Fischer \& Colley (2005) on Ilha Rasa, an island in the municipality of Guaraqueçaba, on the northern coast of Paraná, where $83.3 \%$ of the interviewees associated the appearance of L. fulica with the heavy summer rains. Carvalho Junior \& Nunes (2009) recorded a similar situation in Várzea Grande, in the Brazilian state of Mato Grosso, where $90.9 \%$ of the population associated the appearance of the mollusk with the rainy season.

None of the residents interviewed were aware of techniques for the eradication of the species. This indicates that the city's administration has not followed the recommendations of IBAMA normative instruction number 18/2005 (IBAMA 2005), which authorizes local authorities to employ measures of collection, control, and elimination of L. fulica as a means of impeded the expansion of its populations to local rural areas and other Brazilian regions. Colley (2010) concluded that the first stage in the successful management of L. fulica is the diagnosis of the occurrence and distribution of this invasive snail within the target area, prior to the selection of the most appropriate measure, which should then be adapted to the local context. The rapid advance of the species through the different neighborhoods of the city, and to other areas of the state, together with the lack of adequate knowledge on the management of this problem by local residents, is 
an alarm call for the public authorities of the state, which have, up to now, neglected the presence of the species in Acre. It will be necessary to implement urgent measures to control the invasive populations of L. fulica in order to avoid infestation in the near future.

\section{Final considerations}

Much of the city of Rio Branco is infested with the giant african land snail (L. fulica). However, while the population of Rio Branco is aware of the presence of L. fulica in its houses and neighborhoods, there is a general lack of knowledge on the adequate procedures for the management of its populations. Municipal and state authorities should thus adopt immediate preventive measures, such as informative leaflets and announcements in the local media, to increase the awareness of the local population and encourage the management and control of the $L$. fulica population.

\section{Acknowledgments}

We are grateful to $\mathrm{CNPq}$ for providing MSL with an undergraduate research stipend. We would also like to thank the research team at the National Schistosomiasis Reference Laboratory at the Oswaldo Cruz Foundation in Rio de Janeiro, and in particular the lab coordinator, Mônica A. Fernandez, for analyzing our specimens. We are also grateful to the residents of the neighborhoods of Rio Branco who kindly welcomed us and contributed to the research by answering the questionnaires. We would also like to thank two anonymous reviewers for their comments on a previous version of this paper.

\section{Author Contributions}

Marcos Silva de Lima: Collected and analyzed the data, and drafted the first version of the manuscript.

Edson Guilherme: Formulated the original research project, contributed to the data analyses, and wrote the final version of the manuscript.

\section{Conflicts of interest}

The authors declare that they have no conflict of interest related to the publication of this manuscript.

\section{References}

ANDERSEN, E., GUBLER, P.J., SORENSEN, K., BEDDARD, J. \& ASH, L.R. 1986. First Report of Angiostrongylus cantonensis in Puerto Rico. Am J Trop Med Hyg. 35(2): 319-322.

AGUIAR, P.H., MORENO, P. \& PASCUAL, J. 1981. First record of Angiostrongylus cantonensis in Cuba. Am J Trop Med Hyg. 30(5): 963-965.

ALBUQUERQUE, F.S., PESO-AGUIAR, M.C., ASSUNÇÃO-ALBUQUERQUE, M.J.T. \& GALVEZ, L. 2009. Do climate variables and human density affect Achatina fulica (Bowditch) (Gastropoda: Pulmonata) Shell length, total weight and condition factor? Braz J Biol. 69(3): 879-885.

BONFIM, T.C.S., JUNIOR, A.M., TUNHOLI, V.M., ALVES, V.M.T., FARO, M.J., MOTA, E.M., SILVANA, T.C.B., PINHEIRO, J. \& GARCIA, J.S. 2013. Biochemical and histopathological alterations in Biomphalaria glabrata due to co-infection by Angiostrongylus cantonensis and Echinostoma paraensei. J Invertebr Patho. 115 (1): 80-85.
CALDEIRA, R.L., MENDONÇA, C.L.G.F., GOVEIA, C.O., LENZI, H.L., TEIXEIRA, C.G., LIMA, W.S., MOTA, E.M., PECORA, I.L., MEDEIROS, A.M.Z. \& CARVALHO, O.S. 2007. First record of molluses naturally infected with Angiostrongylus cantonensis (Chen, 1935) (Nematoda: Metastrongylidae) in Brazil. Mem I Oswaldo Cruz. 102(7): 887-889.

CARVALHO JUNIOR, V.C.B. \& NUNES, J.R.S. 2009. Ocorrência e distribuição do caramujo africano "Achatina fulica" Bowdich, 1822, no município de Várzea Grande - MT. Unipinhal 6: 606-620.

COELHO, L.M. 2005. Informe técnico para o controle do caramujo africano (Achatina fulica, Bowdich 1822) em Goiás, Goiânia-GO. Agência rural 4: 1-12.

COLLEY, E. 2010. Medidas de controle de Achatina fulica. In: Fischer, M.L. \& Costa, L.C.M.O.(Eds). O caramujo gigante africano Achatina fulica no Brasil. Champagnat Editora - PUCPR, p. 203-230.

COLLEY, E. \& FISCHER, M.L. 2009. Avaliação dos problemas enfrentados no manejo do caramujo gigante africano Achatina fulica (Gastropoda: Pulmonata) no Brasil. Zoologia. 26(4):674-683.

DUARTE, A.F. 2006. Aspectos da climatologia do Acre, Brasil, com base no intervalo 1971-2000. Rev Bras Meteorol. 21(3b): 308-317.

ESPÍRITO-SANTO, M.C.C., PINTO, P.L.S., MOTA, P.J.G. \& GRYSCHEK, R.C.B. 2013. The first case of Angiostrongylus cantonensis eosinophilic meningitis diagnosed in the city of São Paulo, Brazil. Rev Inst Med Trop. 55(2): 129-132.

FISCHER, M.L. \& COLLEY, E. 2004. Diagnóstico da ocorrência do caramujo gigante africano Achatina fulica BOWDICH, 1822 na Apa de Guaraqueçaba, Paraná, Brasil. Estud Biol. 26(54): 43-50.

FISCHER, M.L \& COLLEY, E. 2005. Espécie invasora em reservas naturais: caracterização da população de Achatina fulica Bowdich, 1822 (Mollusca - Achatinidae) na Ilha Rasa, Guaraqueçaba, Paraná, Brasil. Biota Neotrop. 5(1): 127-144.

FONTANILLA, I.K.C. 2010. Achatina (Lissachatina) fulica Bowdich: its molecular phylogeny, genetic variation in global populations, and its possible role in the spread of the rat lungworm Angiostrongylus cantonensis (Chen). $\mathrm{PhD}$ thesis, University of Nottingham.617p.

FONTANILLA, I.K.C., MARIA, I.M.P.S., GARCIA, J.R.M., GLATE, H., NAGG, F. \& WADE, C.M. 2014. Restricted genetic variation in populations of Achatina (Lissachatina) fulica outside of east Africa and the indian ocean islands points to the indian ocean islands as the earliest known common source. PLoS ONE. 9(9): e105151.

GOLDYN, B., GUAYASAMIN, P.R., SANCHEZ, K.A. \& HEPTING, L. 2016. Notes on the distribution and invasion potential of Achatina fulica Bowdich, 1822 (Gastropoda: Pulmonata: Achatinidae) in Ecuador Folia Malacol. 24(2): 85-90.

GOLDYN, B., KACZMARE, L., ROSZKOWSKA, M., GUAYASAMÍN, P.R., KSIĄŻKIEWICZ, Z. \& CERDA, H. 2017. Urban ecology of invasive giant African snail Achatina fulica (Férussac) (Gastropoda: Achatinidae) on its first recorded sites in Ecuadorian Amazonia. Am Malacol Bull. 35(1): 1-6.

GISD. 2018. Global Invasive Species Database. (http://www.iucngisd.org/gisd/ speciesname/ Achatina+fulica). Accessed on 21-03-2018.

HOCHBERG, N.S., PARK, S.Y., BLACKBURN, B.G., SEJVAR, J.J., GAYNOR, K., CHUNG, H., LENIEK, K., HERWALDT, B.L. \& EFFLER, P.V. 2007. Distribution of Eosinophilic Meningitis Cases Attributable to Angiostrongylus cantonensis, Hawaii. Emerg Infect Dis. 13: $1675-1680$.

HUNG,T.P. \& CHEN, E.R. 1988. Angistrongiliasis (Angiostrongylus cantonensis). Handb Clin Neurol . 52: 545 - 562.

IBAMA. 2005. Instrução Normativa $N^{0} 73$, de 18 de Agosto de 2005. Ministério do Meio Ambiente. Brasília. DF.

IWANOWICZ, D.D., SANDERS, L R., SCHILL, W.B., XAYAVONG, M. V., DA SILVA, A. J., QVARNSTROM, Y., \& SMITH, T. 2015. Spread of the rat lungworm (Angiostrongylus cantonensis) in giant African land snails (Lissachatina fulica) in Florida, USA. Journal of Wildlife Diseases, 51: 749-753. 
JARVI, S. I., FARIAS, M. E. M., HOWE, K., JACQUIER, S., HOLLINGSWORTH, R. \& PITT, W. 2012. Quantitative PCR estimates Angiostrongylus cantonensis (rat lungworm) infection levels in semi-slugs (Parmarion martensi). Mol Biochem Parasitol. 185: 174-176.

LAI, P.Y., FUNASAKI, G.Y. \& HIGA, S.Y. 1982. Introductions for Biological Control in Hawaii: 1979 and 1980. Hawaii Entomol Soc. 24: 109-111.

LIMA, A.R.M.C., MESQUITA, S.D., SANTOS, S.S., AQUINO, E.R.P., ROSA, L.R.S., DUARTE, F.S., TEIXEIRA, A.O., CARTA, Z.R.S. \& FERREIRA, M.L.B. 2009. Neuroinfestation by Angiostrongylus cantonensis in Recife, Pernambuco, Brazil. Arq Neuro-Psiquiat. 67(4): 1093-1096.

MARTINS, R.M. \& DONATELLI, R.J. 2014. Predação de caramujo-africano (Achatina fulica) pelo gavião-caracoleiro (Chondrohierax uncinatus) em Pirajuí , interior do estado de São Paulo. Atual Ornitol. 178: 6-8.

MIRANDA, M.S., FONTENE, J.H. \& PECORA, I.L. 2014. Population structure of a native and an alien species of snail in an urban area of the Atlantic Rainforest. J Nat Hist. 49(1-2): 19-35.

MORASSUTTI, A.L., THIENGO, S. C., FERNANDEZ, M., SAWANYAWISUTH, K. \& TEIXEIRA, C. G. 2014. Eosinophilic meningitis caused by Angiostrongylus cantonensis: an emergent disease in Brazil. Mem Inst Oswaldo Cruz. 109 (4): 399-407.

MOREIRA, V.L.C., GIESE, E.G., MELO, F.T.V., SIMÕES, R.O., THIENGO, S.C., MALDONADO, A. \& SANTOS, J.N. 2013. Endemic angiostrongyliasis in the Brazilian Amazon: Natural parasitism of Angiostrongylus cantonensis in Rattus rattus and $R$. norvegicus, and sympatric giant African land snails, Achatina fulica. Acta Trop. 125:90-97.

MOTA, E. M. \& LENZI, H. L. 1995. Angiostrongylus costaricensis life cicle: A new proposal. Mem Ins Oswaldo Cruz. 90(6): 707-709.

MORERA, P. \& CÉSPEDES, R. 1971. Angiostrongilosis Abdominal. Una nueva parasitosis humana. Acta Médica Cost. 14(3): 159-173.

MURPHY, B. 2001. Breeding and Growing Snails Commercially in Australia, RIRDC-Rural Industries Research Development Corpofeed, Kingston, $39 \mathrm{p}$.

OHLWEILER, F.P., GUIMARÃES, M.C.A., TAKAHASHI, F.Y. \& EDUARDO, J.M. 2010. Current distribution of Achatina fulica, in the state of São Paulo including records of Aelurostrongylus abstrusus (Nematoda) larvae infestation. Rev Inst Med Trop São Paulo. 52(4): 211-214.

OLIVEIRA, A.P.M., GENTILE, R., JUNIOR, A.M., TORRES, E.J.L \& THIENGO, S.C. 2015. Angiostrongylus cantonensis infection in molluscs in the municipality of São Gonçalo, a metropolitan area of Rio de Janeiro, Brazil: role of the invasive species Achatina fulica in parasite transmission dynamics. Mem Inst Oswaldo Cruz. 110(6): 739-744.

OLIVEIRA, J.C.S., GONÇALVES, T.S., MONTEIRO, P.R., SARAIVA, I.O. \& VASCONCELOS, H.C.G. 2013. Ocorrência de Achatina fulica (MOLLUSCA: PULMONATA: ACHATINIDAE) em três bairros da cidade de Macapá, Amapá. Biota Amazônia. 3(1): 9-12.

PENA, G.P.M., ANDRADE FILHO, J.S. \& ASSIS, S.C. 1995. Angiostrongylus costarisensis: First record of its occurrence in the state of Espírito Santo, Brazil, and review of its geographic distribution. Rev. Inst. Med Trop São Paulo. 37(4): 364-374.

RACCURT, C.P., BLAISE, J. \& DURETTI-DESSET, M.C. 2003. Présence d'Angiostrongylus cantonensis en Haïti. Trop Med Int Health. 8(5): 423-426.

RAUT, S.K. \& BARKER, G.M.C. 2002. Molluscs as Crops Pests (Edited by G.M. Barker). CABI Publishing: Wallingford, 64p.
RODA, A., NACHMAN, G., WEIHMAN, S., YONG CONG, M. \& ZIMMERMAN, F. 2016. Reproductive Ecology of the Giant African Snail in South Florida: Implications for Eradication Programs. PLoS ONE. 11(11): e0165408.

SANKARAN, K.V. 2004. Snail, Asia - Pacific Forest Invasive Species: Giant African. Pest Fact Sheet. http://archives.eppo.int/MEETINGS/2013 conferences/communication/03 Sankaran/index.html. Acessed on: 11/10/2017.

SANTOS, J.N., MELO, F.T.V., NAZARE, L.C., FURTADO, A.P. \& GIESE, E.G. 2013. Strongyluris amazonicus n. sp. (Nematoda: Heterakidae): A parasite of Tropidurus oreadicus from the Brazilian Amazon. Acta Trop. 128(1): 96-102.

SILVA, J.M.F., FONSECA, I.M.P., CARVALHO, L.M.M., MEIRELE, J.A.F.S. \& FAZENDEIRO, I. 2005 Pneumonia em gato por Aelurostrongylus abstrusus - necessidade de um diagnóstico precoce. Rev Port Ciênc Vet. 100: 103-106.

SMITH, T.R., WHITE-MCLEAN, J., DICKENS, K., HOWE, A.C. \& FOX, A. 2013. Efficacy of four molluscicides against the giant African snail, Lissachatina fulica (Gastropoda: Pulmonata: Achitinidae). Fla Entomol. 96(2): 396-402.

SRIDHAR, V., VINESH, L.S. \& JAYASHANKAR, M. 2014. Mapping the potential distribution of Achatina fulica (Bowdich) (Stylommatophora: Achatinidae) in India using CLIMEX, a bioclimatic software. Pest Manag. Hort Ecosyst. 20(1): 14-21.

TATAYAH, R., MALHAM, J. \& HAVERSON, P. 2007. The use of copper strips to exclude invasive African giant land-snails Achatina spp. from echo parakeet Psittacula eques nest cavities, Black River Gorges. Conservation Evidence. 4: 6-8

TEIXEIRA, D.G., GUERRA, J.L., SILVA, Z., AZARIAS, R.E.G.R. \& MARTINS, M.F. 2008. Spectosmacroscópicos da anatomia do sistema reprodutor de escargots: Achatina fulica e Achatina monochromatica. Braz J Vet Res Anim Sci 45(5): 333-338

THIENGO, S.C., FARACO, F.A., SALGADO, N.C., COWIE, R.H. \& FERNANDEZ, M.A. 2007. Rapid spread of an invasive snail in South America: The giant African snail, Achatina fulica, in Brasil. Biol Invasions. 9(6): 693-702.

THIENGO, S.C., FERNANDEZ, M.A., TORRES, E.J.L., COELHO, P.M. \& LANFREDI, R.M. 2008. First record of a nematode Metastrongyloidea (Aelurostrongylus abstrusus larvae) in Achatina (Lissachatina) fulica (Mollusca, Achatinidae) in Brazil. J Invertebr Pathol. 98(1): 34-39.

THIENGO, S.C. \& FERNANDEZ, M.A. 2013. Gastrópodes Neotropicais de importância médica. In Dinâmica das Doenças Infecciosas e Parasitárias, Vol. I (J. R. Coura, ed.) Guanabara Koogan, Rio de Janeiro, p. 131-140. (a)

THIENGO, S.C., SIMÕES, R. O., FERNANDEZ., M. A., \& JÚNIOR, M. 2013. Angiostrongylus cantonensis and Rat Lungworm Disease in Brazil. Hawaii J Med Public Health. 72 (6 suppl 2): 18-22. (b)

TOMIYAMA, K. \& NAKANE, M. 1993. Dispersal patterns of the giant african snail, Achatina fulica (Férussac) (Stylommatophora: Achatinidae), equipped with a radio-transmitter. J Mollusc Stud. 59(3): 315-322.

WALLACE, G.D. \& ROSEN, L.1969. Studies on eosinophilic meningitis: experimental infection of rats and other homoiothermic vertebrates with Angiostrongylus cantonensis. Am J Epidemiol. 89(3): 331-344. (a)

WALLACE, G.D. \& ROSEN, L.1969. Studis on Studies on Eosinophilic Meningitis V. Molluscan Hosts ofAngiostrongylus cantonensison Pacific Islands. Am J Trop Med Hyg. 18(2): 206-216. (b) 